\title{
Leaf-cutting ant attack in initial pine plantations and growth of defoliated plants
}

\author{
Mariane Aparecida Nickele(1), Wilson Reis Filho(2), Edilson Batista de Oliveira ${ }^{(2)}$, Edson Tadeu lede ${ }^{(2)}$, \\ Nádia Caldato ${ }^{(3)}$ and Priscila Strapasson ${ }^{(1)}$
}

\begin{abstract}
(1)Universidade Federal do Paraná, Departamento de Zoologia, Caixa Postal 19020, CEP 81531-980 Curitiba, PR, Brazil. E-mail: nickele.mariane@gmail.com, pri_strapasson@yahoo.com.br (2)Embrapa Florestas, Estrada da Ribeira, Km 111, Caixa Postal 319, CEP 83411-000 Colombo, PR, Brazil. E-mail: wilson@cnpf.embrapa.br, edilson@cnpf.embrapa.br, iedeet@cnpf.embrapa.br (3)Faculdade de Ciências Agronômicas, Departamento de Produção Vegetal, Caixa Postal 237, CEP 18610-307 Botucatu, SP, Brazil. E-mail: nacbiol@gmail.com
\end{abstract}

\begin{abstract}
The objective of this work was to evaluate the natural attack by Acromyrmex crassispinus in initial Pinus taeda plantations without control measures against ants, as well as the effect of defoliation in seedlings of $P$. taeda. Evaluations of the attack of leaf-cutting ants on P. taeda plantations were done monthly in the first six months, then 9 and 12 months after planting. The percentages of plants that were naturally attacked by ants were registered. The effect of defoliation was evaluated by artificial defoliation, simulating the natural patterns of attack by $A$. crassispinus on $P$. taeda seedlings. The natural attack of $A$. crassispinus was greater during the first months after planting, being more intense in the first 30 days. Artificial defoliation indicated that there were no significant losses in diameter and height in plants with less than $75 \%$ defoliation. However, there were significant losses in diameter and height in plants with $100 \%$ defoliation, independently of the cut of the apical meristem, and also plant death. The control of leaf-cutting ants in P. taeda plantings, in which A. crassispinus is the most frequent leaf-cutting ant, should be intense only at the beginning of planting, since the most severe attacks occur during this time.
\end{abstract}

Index terms: Acromyrmex crassispinus, Pinus taeda, artificial defoliation, forest pest.

\section{Ataque de formigas cortadeiras em plantios iniciais de pinus e crescimento de plantas desfolhadas}

\begin{abstract}
Resumo - O objetivo deste trabalho foi avaliar o ataque natural de Acromyrmex crassispinus em plantios iniciais de Pinus taeda sem controle contra formigas, bem como o efeito da desfolha em mudas de P. taeda. As avaliações do ataque de formigas cortadeiras em plantios de $P$. taeda foram realizadas mensalmente nos primeiros seis meses, depois aos 9 e 12 meses após o plantio. As percentagens de plantas naturalmente atacadas por formigas foram registradas. $\mathrm{O}$ efeito da desfolha foi avaliado por meio do desfolhamento artificial, ao se simularem os ciclos naturais de ataque de A. crassispinus em mudas de $P$. taeda. $\mathrm{O}$ ataque natural de A. crassispinus foi maior nos primeiros meses após o plantio, tendo sido mais intenso durante os primeiros 30 dias. A desfolha artificial indicou que não houve perdas significativas no diâmetro e na altura de plantas com menos de $75 \%$ de desfolha. No entanto, observaram-se perdas significativas no diâmetro e na altura de plantas $100 \%$ desfolhadas, independentemente do corte da gema apical, e também a morte de plantas. O controle de formigas cortadeiras em plantios de $P$. taeda, em que A. crassispinus é a formiga cortadeira mais frequente, deve ser intenso somente no início do plantio, pois os ataques mais severos ocorrem neste período.
\end{abstract}

Termos para indexação: Acromyrmex crassispinus, Pinus taeda, desfolha artificial, praga florestal.

\section{Introduction}

In Brazil, approximately two million hectares are planted with different Pinus species. In the South of the country, about $80 \%$ of the planted forests consist of Pinus taeda, due to the high productivity and quality of the raw materials (Abraf, 2011). The implementation of development plans to expand the forest base with fast-growth species contributes to industrial enterprises (Hoeflich, 2004). However, extensive planting of forest monocultures creates favorable environments for the establishment of insects that can become pests. Among these insects, the leaf-cutting ants are one of the most important forest pests in South America, considering the damage caused in forest plantings (Cherrett, 1986). 
Leaf-cutting ants are well known because of their remarkable effects on vegetation as herbivores. They can remove up to $15 \%$ of the standing leaf crop (Wirth et al., 2003; Urbas et al., 2007). The damages caused by leaf-cutting ants in forest plantations are greater in one to three-year-old plants, and, in the first months after planting, the losses from those insects can be irreversible, since seedlings are fragile and more easily injured (Vasconcelos \& Cherrett, 1997).

The damages caused by leaf-cutting ants also decrease the resistance of the plants, which become more susceptible to attacks from other insects (Cantarelli et al., 2008). Furthermore, there are costs with chemical products for pest control. In extensive monocultures, this control utilizes massive amounts of broad spectrum insecticides that are toxic to other animals and persist in the environment (Ying \& Kookana, 2006).

Acromyrmex crassispinus is the most common leaf-cutting ant species in southern Brazil (Rando \& Forti, 2005), especially in P. taeda plantations located in northern Santa Catarina State (Nickele et al., 2009). This species causes high levels of damage, which can be attributed to the number of nests in the area and the high number of plant species that are attacked by those ants (Link et al., 2000). Therefore, A. crassispinus has a great economic importance in $P$. taeda reforestation (Lopes et al., 2004). However, little is known about the damages caused by this species on $P$. taeda plantations.

A study in Argentina showed that $20.8 \%$ of the recently-planted $P$. taeda seedlings were attacked by Acromyrmex spp. during the first 65 days after planting (Cantarelli, 2005). However, this percentage of attack included all plants that showed any intensity of attack, i.e., plants partially or totally defoliated. Studies on the attack of leaf-cutting ants on different levels of defoliation in P. taeda plants are still necessary. Knowing the intensity of $A$. crassispinus attacks in $P$. taeda plants is extremely important because not all ant attacks necessarily result in plant damage. Moreover, it is possible to optimize leaf-cutting ant control with knowledge of the real damage caused by ants in P. taeda plantings.

The objective of this work was to evaluate the natural attack by $A$. crassispinus in initial $P$. taeda plantations without control measures against ants, as well as the effect of defoliation in seedlings of $P$. taeda.

\section{Materials and Methods}

The first experiment was carried out at Rio Negrinho (26 $15^{\prime} 16^{\prime \prime} \mathrm{S}$ and $49^{\circ} 31^{\prime} 06^{\prime \prime} \mathrm{W}$, at a $790-\mathrm{m}$ altitude) and Três Barras $\left(26^{\circ} 06^{\prime} 23^{\prime \prime} \mathrm{S}\right.$ and $50^{\circ} 19^{\prime} 20^{\prime \prime} \mathrm{W}$, at a $802-\mathrm{m}$ altitude), both in the north plateau of the state of Santa Catarina, Brazil. Recently-planted P. taeda plantations were selected: Pinus had been previously planted in the Rio Negrinho area and Eucalyptus in Três Barras. Three 1.0-ha plots without control against ants were demarcated (100x100 m) in each area. In Rio Negrinho, planting was done in February 2007 (2,000 plants per hectare), and in Três Barras, in March 2007 (1,600 plants per hectare). All the plants in each plot were evaluated, totaling 6,000 plants in Rio Negrinho and 4,800 plants in Três Barras in each evaluation.

In the experimental areas, 4 and 11 nests per hectare were found, on average, in Rio Negrinho and Três Barras, respectively (Nickele et al., 2009), and no native vegetation was observed among the planting lines in the first month after planting, due to soil preparation for the planting of seedlings.

Based on a preliminary evaluation of the experimental areas, a classification was established according to the natural patterns of attack by $A$. crassispinus on P. taeda seedlings: level 1, 1-50\% defoliation; level 2, 51-75\% defoliation; level 3, 76-100\% defoliation, without the cut of the apical meristem; and level 4, 100\% defoliation, including the cut of the apical meristem. The percentages of plants that were naturally attacked by ants in each level were registered. The percentages of plants killed by ant attack or other factors (drought, stress after planting, and seedling quality) were also recorded.

The evaluations were done monthly in the first six months, then 9 and 12 months after planting. On Rio Negrinho: March 2007, April 2007, May 2007, June 2007, July 2007, August 2007, November 2007, and Febuary 2008; on Três Barras: April 2007, May 2007, June 2007, July 2007, August 2007, September 2007, December 2007, and March 2008. Analysis of variance, followed by Tukey's post-hoc test, at $5 \%$ probability, was used to compare the number of plants that were naturally attacked by ants in each month for each attack level and the number of plants killed by ant attack or other factors in each month. The data were log-transformed (base 10) to meet the assumptions of parametric statistics, when necessary. 
The second experiment was carried out at São Mateus do Sul $\left(25^{\circ} 58^{\prime} 56^{\prime \prime} \mathrm{S}\right.$ and $50^{\circ} 23^{\prime} 49^{\prime \prime} \mathrm{W}$, at a 766-m altitude), in the south of Paraná State, Brazil, where the planting of $P$. taeda seedlings was done in August 2007. Artificial defoliation simulating the natural patterns of attack by $A$. crassispinus on $P$. taeda seedlings was done to evaluate which of the previously described attack levels caused damage in P. taeda plants. The experimental defoliation levels considered were: level 0, control; level 1, 50\% defoliation; level 2, 75\% defoliation; level 3, 100\% defoliation, without the cut of the apical meristem; and level 4, 100\% defoliation, including the cut of the apical meristem. The artificial defoliation was done in the plant starting from the basal to the apical leaves. The leaves were cut by hand with hand pruning shears. The leaf-cutting ants were controlled in this area by applications of granulated baits, and the plants were 30 days old when the experiment was done.

The experimental design was a randomized complete block, and artificial defoliation was done on 20 plants for each attack level. Twenty plants that did not suffer defoliation were selected as the control (level 0). Each plant was numbered and identified with a defoliation level. One planting line was used for each attack level, and the defoliated plants were equidistanced from each other by $12.5 \mathrm{~m}$ in each planting line. The distance between each attack level was $2.5 \mathrm{~m}$.

The assessments were done every six months, measuring the collar diameter of the plants to $5 \mathrm{~cm}$ above ground and the height of the plants until they were 36 months old. Analysis of variance, followed by Tukey's post-hoc test, at 5\% probability, was used to compare the growth of the plants defoliated at different levels. The data were log-transformed (base 10) to meet the assumptions of parametric statistics, when necessary.

\section{Results and Discussion}

The percentage of plants attacked naturally was higher in the first months after planting in Rio Negrinho (Figure $1 \mathrm{~A}$ ) and Três Barras (Figure $1 \mathrm{~B}$ ). In Rio Negrinho, the largest percentage of attacked plants was observed in the first month after planting, and attacks in levels 1, 2, and 3 occurred in approximately $7 \%$ of the plants in each level. Level 4 occurred in approximately $3 \%$ of the plants in this period (Figure $1 \mathrm{~A}$ ). Subsequent evaluations showed that the percentage of attacked plants decreased in all levels of defoliation. In Três Barras, the percentage of attacked plants in the first month after planting was $1.5,2.7,9$, and $0.5 \%$ of the plants, for levels 1, 2, 3, and 4, respectively (Figure 1 B). The subsequent percentages of attacked plants decreased, except in the last evaluation, in which there was an increase in the percentage of attacked plants in levels 1 and 2. Level 4 was significantly more intense in the first month after planting and occurred during the first four months after planting, in both experimental areas.

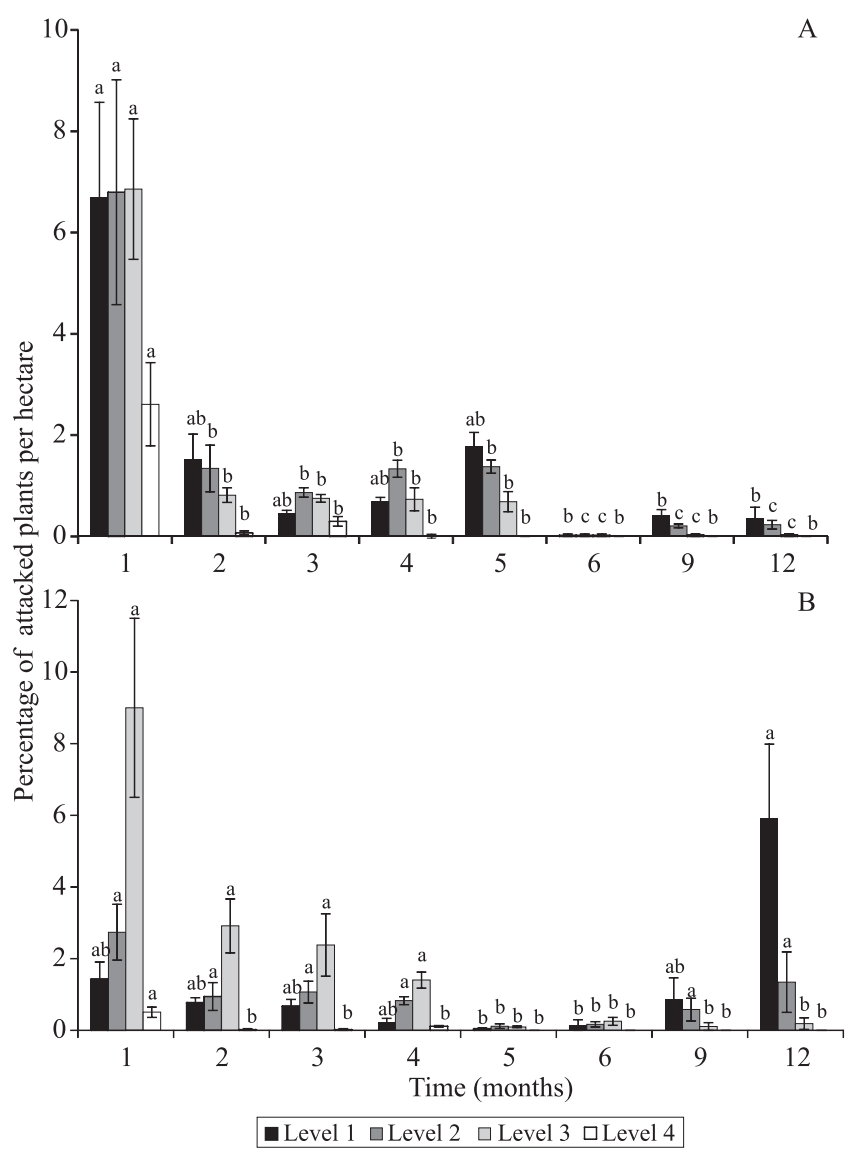

Figure 1. Percentage (Mean $\pm \mathrm{SE}$ ) of Pinus taeda plants naturally attacked by Acromyrmex crassispinus, in different defoliation levels: Level 1, 1-50\% defoliation; Level 2, 51-75\% defoliation; Level 3, 76-100\% defoliation, without the cut of the apical meristem; and Level 4, 100\% defoliation, including the cut of the apical meristem. A, Rio Negrinho, SC; B, Três Barras, SC. Different letters indicate significant differences among treatments (months) for each attack level according to Tukey's test, at 5\% probability. 
In a study in Argentina, $20.8 \%$ of the recently-planted $P$. taeda seedlings were attacked by $A$. heyeri and A. lobicornis, during the first 65 days after planting, but there was a reduction in the herbivory rate along time, as observed in the present study (Cantarelli, 2005). In another study, more than $50 \%$ of the needles of $P$. contorta were harvested by leaf-cutting ants in northern Patagonia, Argentina, and there was a complete defoliation of seedlings (Pérez et al., 2011).

The plants killed by ants were totally defoliated in the present study. The total percentage of plants killed by ant attack was 4.41 and $7.51 \%$ per hectare in Três Barras and Rio Negrinho, respectively (Figure 2). The mortality of plants killed by ants was significantly higher in the first two and five months after planting, in Rio Negrinho and Três Barras, respectively. The total percentage of dead plants due to other factors was

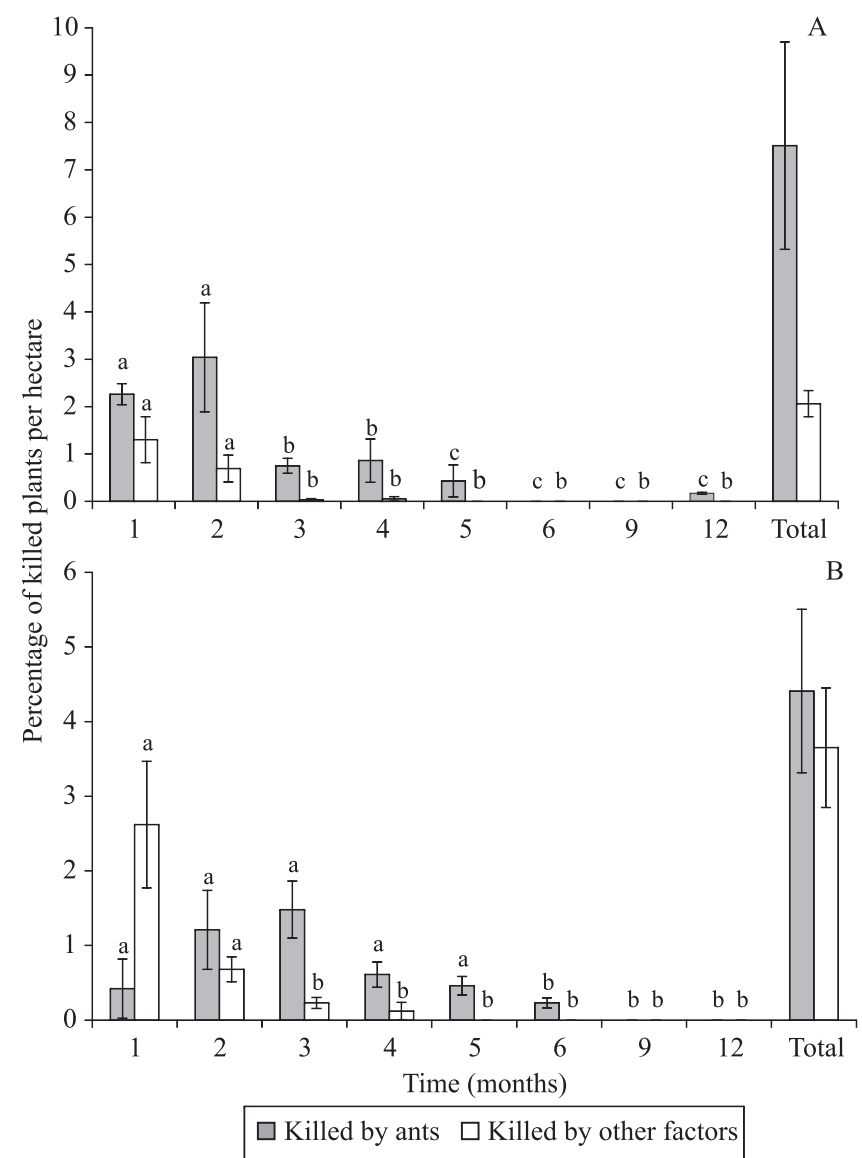

Figure 2. Percentage (Mean $\pm \mathrm{SE}$ ) of Pinus taeda plants killed by ant attack or other factors. A, Rio Negrinho, SC; B, Três Barras, SC. Different letters indicate significant differences among treatments (months) for each kind of mortality according to Tukey's test, at 5\% probability.
$2.06 \%$ in Rio Negrinho and 3.65\% in Três Barras, and was significantly higher in the first two months after planting. In the state of São Paulo, Brazil, one old Atta nest can kill 5\% of a six-year-old Eucalyptus plantation and $10 \%$ of an eight-year-old Pinus plantation every year (Amante, 1967). A single colony of Atta leaf-cutting ants caused $48 \%$ of conifer seedling mortality and reduced growth in $40 \%$ of the surviving fraction in a 2.0-ha area in a Venezuelan forest plantation (Jaffé, 1986).

The largest percentage of attacked plants was observed in the first month after planting. This could be attributed to the fact that the ants did not have any other foraging options in the first month after planting, since there was no native vegetation among the planting lines, due to soil preparation for the planting of seedlings. The percentage of attacked plants decreased in the subsequent months, probably due to the appearance of native vegetation, which offered other forage options for the ants. Therefore, the native vegetation among the planting lines, when not competitive with the cultivated plants, should be maintained, since it supplies food and cover for several natural enemy species and other types of plants that serve as substrate for the fungus cultivated by leaf-cutting ants (Araújo et al., 2003). Moreover, younger plants are more susceptible to attacks than older ones, as indicated by the reduction of attacks in the subsequent months. The leaf-cutting ants prefer young leaves, because the older ones contain inhibitory substances (Farji-Brener, 2001; Mundim et al., 2009).

The effects of different artificial defoliation levels, simulating the natural patterns of A. crassispinus attack on $P$. taeda plants, indicated $100 \%$ survival of the plants classified as level 0,1 , and 2 (control, $50 \%$ defoliation, and $75 \%$ defoliation, respectively). However, level 3 (100\% defoliation, without the cut of the apical meristem) and level 4 (100\% defoliation, including the cut of the apical meristem) caused 15\% of plant mortality in each level, during the first six months. After this period, there was no plant mortality. These results were similar to the first experiments, in which the plants killed by ant attack were $100 \%$ defoliated. Approximately $8 \%$ of totally defoliated $E$. grandis plants died (Matrangolo et al., 2010). A study using experimental defoliations that mimicked patterns of attack by Atta spp. in Brazilian Cerrado tree species also showed that total defoliation caused plant mortality 
and that plant mortality is higher depending on how many times the same plant is defoliated (Mundim et al., 2012).

In the artificial defoliation experiments, six months after planting, there were no significant differences in diameter for defoliation levels 0, 1, and 2 (Figure 3 A). No significant differences were observed between levels $0,1,2$, and 3 regarding height (Figure 4 A). Twelve months after planting, there were also no significant differences between levels 0 and 1 in diameter, and the same result was obtained regarding height (Figure 3 $\mathrm{B}$ and $4 \mathrm{~B}$ ). No significant differences were observed $18,24,30$, and 36 months after planting in diameter between levels 0,1 , and 2 or in height (Figures 3 and 4 C, D, E, F).

There was a reduction in plant growth (diameter and height) for plants with $100 \%$ defoliation, independently of the cut of the apical meristem. The
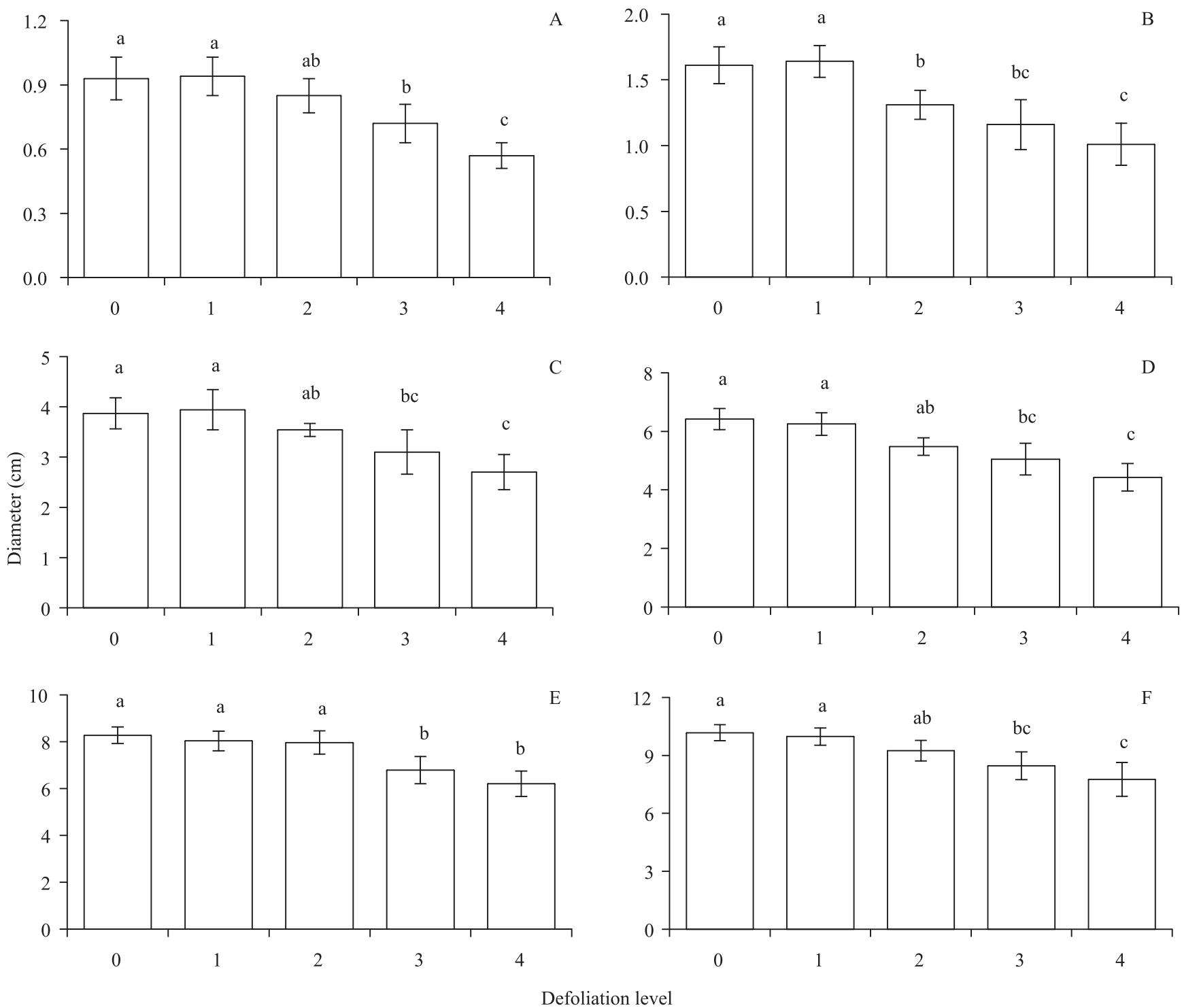

Figure 3. Diameter of Pinus taeda plants artificially defoliated for simulation of Acromyrmex crassispinus attack: A, six months; B, 12; C, 18; D, 24; E, 30; and F, 36 months after planting. Different letters indicate significant differences among treatments according to Tukey's test, at 5\% probability. Level 0, control; level 1, 50\% defoliation; level 2, 75\% defoliation; level 3, 100\% defoliation, without the cut of the apical meristem; and level 4, 100\% defoliation, including the cut of the apical meristem. 
larger the percentage of defoliation, the larger were the losses in diameter and height. This was also observed in artificially defoliated $P$. taeda and E. grandis when the plants were 30 days old (Reis Filho et al., 2011). Different levels of artificial defoliation simulating the attack of leaf-cutting ants on 16-month-old $P$. caribaea also indicated strong tendencies for defoliated trees to suffer greater damage with the increase of defoliation intensity (Ribeiro \& Woessner, 1980).

Levels 1 and 2 did not cause significant losses in plant diameter and height. Only levels 3 and 4
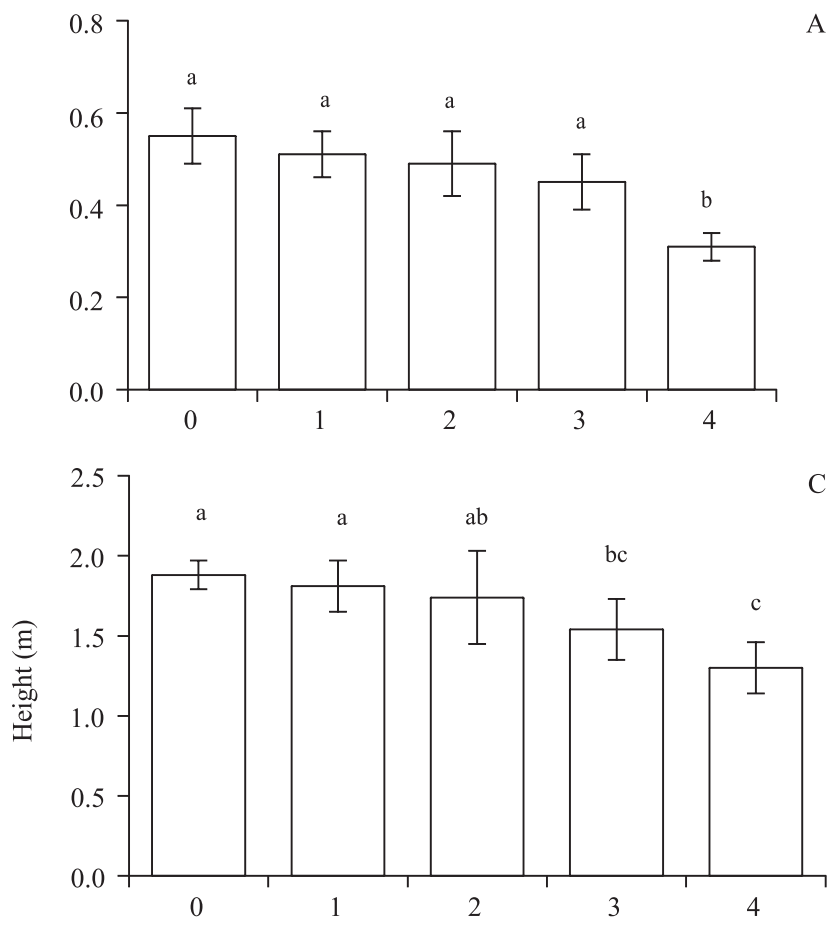

C

A

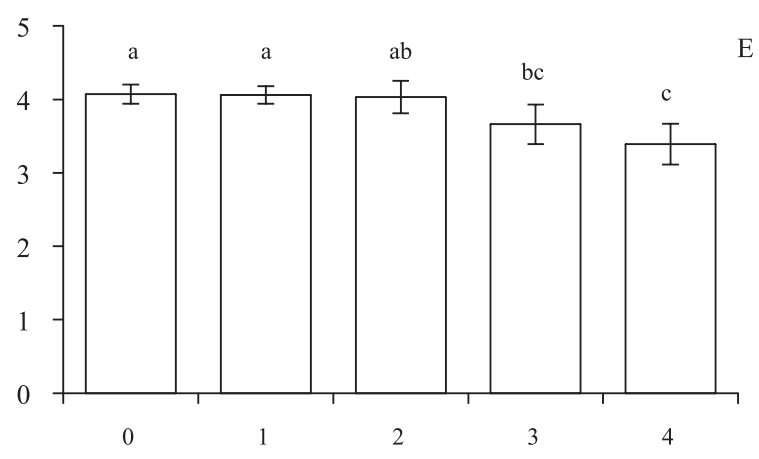

Defoliation level
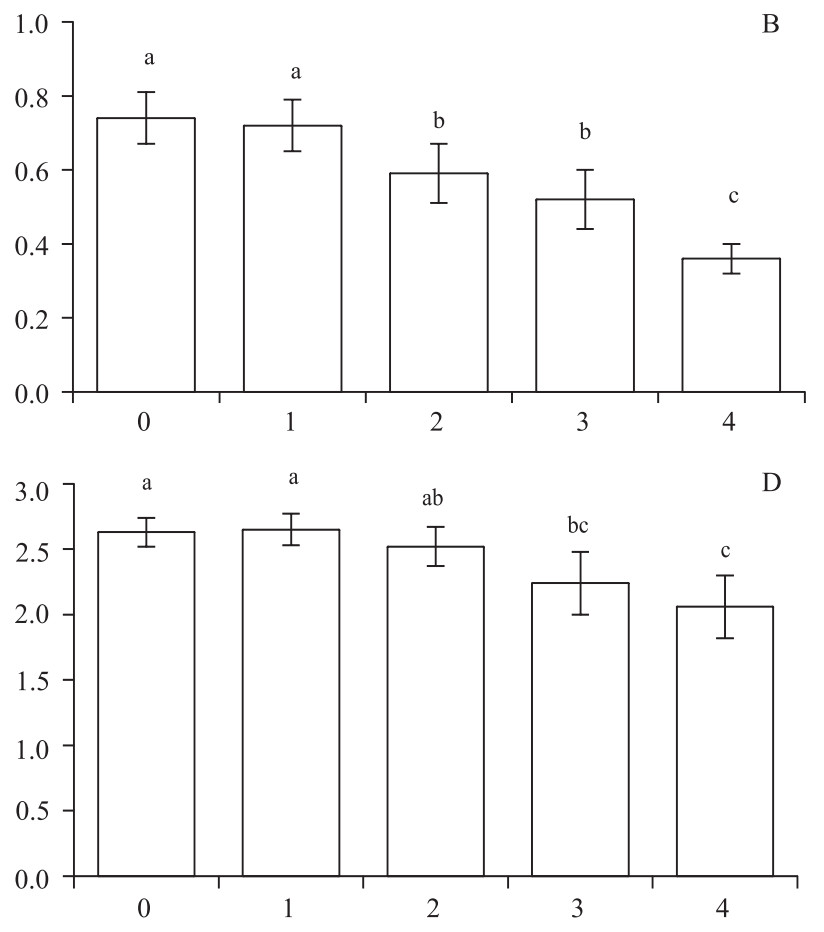

resulted in significant losses in diameter and height, and, consequently, could cause losses in wood production at the end of the planting cycle. The mean losses in growth of plants defoliated in level 3, in comparison to the control, were of $17 \%$ in diameter and $21 \%$ in height, whereas the losses in the growth of defoliated plants in level 4 were of $24 \%$ in diameter and $25 \%$ in height, when plants were 36 months old. Similar results were found in Argentina, where there was a significant reduction in height and diameter of P. taeda attacked by Acromyrmex spp. The defoliated

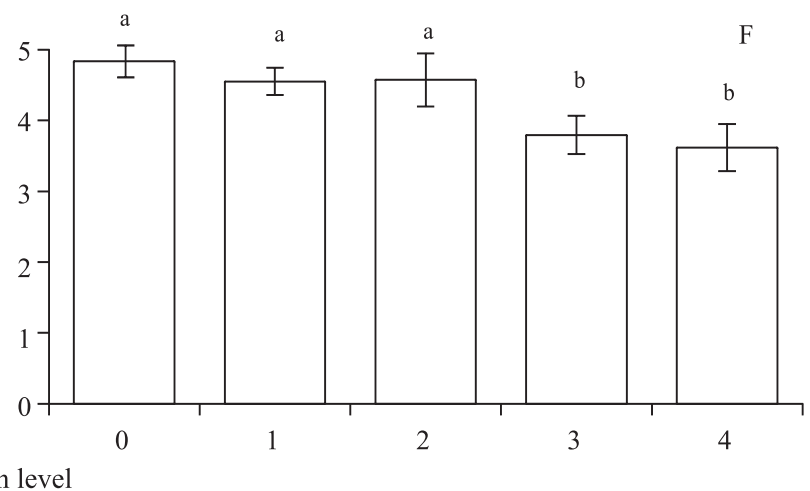

Figure 4. Height of Pinus taeda plants artificially defoliated for simulation of Acromyrmex crassispinus attack: A, six months; B, 12; C, 18; D, 24; E, 30; and F, 36 months after planting. Different letters indicate significant differences among treatments according to Tukey's test, at 5\% probability. Level 0, control; level 1, 50\% defoliation; level 2, 75\% defoliation; level 3, 100\% defoliation, without the cut of the apical meristem; and level 4, 100\% defoliation, including the cut of the apical meristem. 
plants, which were 12 months old, suffered losses of $17.3 \%$ in diameter and $12.2 \%$ in height, when compared to the control (Cantarelli et al., 2008). Plants of E. grandis lost $18.9 \%$ in diameter and $12 \%$ in height with $100 \%$ defoliation (Matrangolo et al., 2010). Plants of E. urophyla lost 16 and $42 \%$ of wood volume at 4.6 years with a defoliation of 75 and 100\%, respectively (Zanúncio et al., 1999). However, levels 3 and 4 were significantly more common only at the beginning of $P$. taeda planting. When the plantation was more than nine months old, level 3 was rarely observed and level 4 did not occur (Figure 1).

The seedlings were artificially defoliated in the first month after planting, since the most severe $A$. crassispinus attack in $P$. taeda occurs during this time (Figure 1). The attack of leaf-cutting ants in 24 to 36-month-old $P$. taeda plants is not significantly harmful to plant development (Cantarelli et al., 2008).

When the percentage of plants naturally attacked by ants was evaluated throughout the year, an increase in the percentage of attacked plants in the last month of evaluation was verified in Três Barras, when the plants were one year old (Figure 1). However, most of plants showed levels 1 and 2 of defoliation, which do not cause plant damage. Therefore, the $A$. crassispinus attack that can cause damage to $P$. taeda plants is concentrated during the first months after planting, with larger impact in the first 30 days. This way, the control of leaf-cutting ants in $P$. taeda plantings, in which $A$. crassispinus is the most frequent leaf-cutting ant, should be intense only at the beginning of planting, since the most severe $A$. crassispinus attack on $P$. taeda plants occurs during this time.

\section{Conclusions}

1. The natural attack of Acromyrmex crassispinus is greater during the first months after planting, with larger impact in the first 30 days.

2. There are no significant losses in diameter and height in plants with less than $75 \%$ defoliation.

3 . There are significant losses in diameter and height in plants with $100 \%$ defoliation, independently of the cut of the apical meristem.

\section{Acknowledgements}

To Battistella Florestal, in Rio Negrinho, SC, Brazil, and Rigesa, in Três Barras, SC, and in São Mateus do Sul, PR, Brazil, for support.

\section{References}

ABRAF. Anuário estatístico da ABRAF 2012: ano base 2010. Brasília: ABRAF, 2011. 150p.

AMANTE, E. Prejuízos causados pela formiga saúva em plantações de Eucalyptus e Pinus no Estado de São Paulo. Silvicultura, v.6, p.355-363, 1967.

ARAÚJO, M. da S.; DELLA LUCIA, T.M.C.; SOUZA, D.J. de. Estratégias alternativas de controle de formigas cortadeiras. Bahia Agrícola, v.6. p.71-74, 2003.

CANTARELLI, E.B. Silvicultura de precisão no monitoramento e controle de formigas cortadeiras em plantios de Pinus. 2005. 108p. Tese (Doutorado) - Universidade Federal de Santa Maria, Santa Maria.

CANTARELLI, E.B.; COSTA, E.C.; PEZZUTTI, R.; OLIVEIRA, L. da S. Quantificação das perdas no desenvolvimento de Pinus taeda após o ataque de formigas cortadeiras. Ciência Florestal, v.18, p.39-45, 2008.

CHERRETT, J.M. The economic importance and control of leafcutting ants. In: VINSON, S.B. (Ed.). Economic impact and control of social insects. New York: Praeger, 1986. p.165-192.

FARJI-BRENER, A.G. Why are leaf-cutting ants more common in early secondary forests than in old-growth tropical forests? An evaluation of the palatable forage hypothesis. Oikos, v.92, p.169-177, 2001.

HOEFLICH, V.F. O papel das florestas para o desenvolvimento da sociedade brasileira. Revista da Madeira, v.14, p.14-20, 2004.

JAFFÉ, K. Control of Atta and Acromyrmex species in pine tree plantations in the Venezuelan llanos. In: LOGFREN, S.; VAN DER MEER, R.K. (Ed.). Fire ants and leaf-cutting ants: biology and management. Colorado: Westview, 1986. p.234-245.

LINK, H.M.; LINK, F.M.; LINK, D. Controle da formiga-preta-pastadeira, Acromyrmex crassispinus, com formicidas em pó. Ciência Florestal, v.10, p.45-56, 2000.

LOPES, J.F.S.; FORTI, L.C.; CAMARGO, R.S. The influence of the scout upon the decision-making process of recruited workers in three Acromyrmex species (Formicidae: Attini). Behavioural Processes, v.67, p.471-476, 2004.

MATRANGOLO, C.A.R.; CASTRO, R.V.O.; DELLA LUCIA, T.M.C.; DELLA LUCIA, R.M.; MENDES, A.F.N.; COSTA, J.M.F.N.; LEITE, H.G. Crescimento de eucalipto sob efeito de desfolhamento artificial. Pesquisa Agropecuária Brasileira, v.45, p.952-957, 2010 .

MUNDIM, F.M.; BRUNA, E.M.; VIEIRA-NETO, E.H.M.; VASCONCELOS, H.L. Attack frequency and the tolerance to herbivory of Neotropical savanna trees. Oecologia, v. 168, p.405414, 2012. 
MUNDIM, F.M.; COSTA, A.N.; VASCONCELOS, H.L. Leaf nutrient content and host plant selection by leaf-cutter ants, Atta laevigata, in a Neotropical savanna. Entomologia Experimentalis et Applicata, v.130, p.47-54, 2009.

NICKELE, M.A.; REIS FILHO, W.; OLIVEIRA, E.B. de.; IEDE, E.T. Densidade e tamanho de formigueiros de Acromyrmex crassispinus em plantios de Pinus taeda. Pesquisa Agropecuária Brasileira, v.44, p.347-353, 2009.

PÉREZ, S.P.; CORLEY, J.C.; FARJI-BRENER, A.G. Potential impact of the leaf-cutting ant Acromyrmex lobicornis on conifer plantations in northern Patagonia, Argentina. Agricultural and Forest Entomology, v.13, p.191-196, 2011.

RANDO, J.S.S.; FORTI, L.C. Ocorrência de formigas Acromyrmex Mayr, 1865, em alguns municípios do Brasil. Acta Scientiarum. Biological Sciences, v.27, p.129-133, 2005.

REIS FILHO, W.; SANTOS, F. dos; STRAPASSON, P.; NICKELE, M.A. Danos causados por diferentes níveis de desfolha artificial para simulação do ataque de formigas cortadeiras em Pinus taeda e Eucalyptus grandis. Pesquisa Florestal Brasileira, v.31, p.37-42, 2011.

RIBEIRO, G.T.; WOESSNER, R.A. Efeito de diferentes níveis de desfolha artificial, para avaliação de danos causados por saúvas (Atta spp.), em árvores de Gmelina arborea Linneé e de Pinus caribaea var. hondurensis Barr., Golf. Anais da Sociedade Entomológica do Brasil, v.9, p.261-272, 1980.

URBAS, P.; ARAÚJO JUNIOR, M.V.; LEAL, I.R.; WIRTH, R. Cutting more from cut forests: edge effects on foraging and herbivory of leaf-cutting ants in Brazil. Biotropica, v.39, p.489-495, 2007.

VASCONCELOS, H.L.; CHERRETT, J.M. Leaf-cutting ants and early forest regeneration in central Amazonia: effects of herbivory on tree seedling establishment. Journal of Tropical Ecology, v.13, p.357-370, 1997.

WIRTH, R.; HERZ, H.; RYEL, R.J.; BEYSCHLAG, W.; HÖLLDOBLER, B. Herbivory of leaf-cutting ants: a case study on Atta colombica in the tropical rainforest of Panama. Berlin: Springer, 2003. 230p. (Ecological studies, 164).

YING, G.G.; KOOKANA, R.S. Persistence and movement of fipronil termiticide with under slab and trenching treatments. Environmental Toxicology and Chemistry, v.25, p.2045-2050, 2006.

ZANÚNCIO,J.C.; RIBEIRO,G.T.;PEREIRA,J.M.M.;ZANUNCIO, T.V. Efeito do desfolhamento causado por formigas cortadeiras em florestas cultivadas. Naturalia, v.24, p.299-304, 1999.

Received on December 22, 2011 and accepted on May 10, 2012 